\title{
PRAKTEK JUAL BELI BATU SUNGAI DALAM TINJAUA N HUKUM ISLAM DI LINGKUNGAN JAMBU TUA KELRAHAN DARMA KECAMATAN POEWALI
}

\author{
Muhammad Alwi, Nur Afifah \\ Hukum Ekonomi Syariah FAI Unasman \\ Prodi Ekonomi Syariah, IAIN Palopo \\ Nurafifah10301997@gmail.com, malwi067@gmail.com
}

\begin{abstract}
Abstrak
Permasalahan dari penelitian ini yaitu pemanfaatan dan pengambilan material sungai sebagai salah satu sumber pendapatan yang berujung pada kerusakan alam. Adanya aktivitas usaha jual beli batu sungai tersebut mendatangkan mudharat yang menyebabkan semakin berkurangnya material batu disekitaran sungai. Tujuan Penelitian ini adalah : 1) Untuk mengetahui bagaimana mekanisme jual beli batu sungai di Lingkungan Jambu tua, 2) Untuk mengetahui tinjauan hukum Islam terhadap jual beli batu sungai di Lingkungan Jambu Tua. Jenis penelitian ini menggunakan jenis penelitian kualitatif. Hasil penelitian menunjukkan bahwa pelaksanaan praktek jual beli batu sungai yang dilakukan oleh masyarakat Lingkungan Jambu Tua yakni masyarakat mengambil dan menjual batu-batuan di sungai dari dalam hingga ke pinggiran sekitar sungai dengan menggali sungai tersebut. Dalam pelaksanaan Praktek jual beli batu sungai di Lingkungan Jambu Tua dengan melihat dari segala manfaat dan mudharat yang ditimbulkan tidak boleh dilakukan dalam ketentuan hukum Islam karena pengambilan batu sungai yang berlebihan akan menyebabkan kerusakan pada sungai dan alam sekitarnya sehingga menimbulkan kemudharatan bagi masyarakat yang lain dan dalam praktek ini telah melanggar aturan dari pemerintah setempat untuk tidak mengambil batu di sekitar sungai tersebut berdasarkan aturan yang berlaku dan tidak sah dalam hukum syariat islam karena menjual barang yang dilindungi oleh pemerintah dan kegiatan tersebut menyebabkan kerusakan alam.
\end{abstract}

Kata kunci: jual beli, hukum islam

\begin{abstract}
The problem of the research is utilization and extraction of river material as one source of income wich leads to the destruction of nature. The business of buying and selling the river rock bring mudharat wich causes the reduction in rock material around the river. The purpose of this research is: 1) To find out how the mechanism of buying and selling river stones in the environment Jambu Tua, 2) to find out a review of Islamic law to the practice of buying and selling river stones in the environment Jambu tua. This type of research uses qualitatuve research. The results of the study show that implementation of the practice of buying and selling river stones conducted by the environment Jambu Tua community which to take stones and sell stones in the river from inside to the river's edge by digging it out. In the practice of buying and selling river stone in environment Jambu Tua by seeing from all the benefits and mudharat caused by these should not be done in the provisions of islamic law because excessive stone uptake will cause damage to the river and nature giving rise to mudharat for other communities and in the implementation of this practice has violated the rules of the local government not to take stones around the river based on applicable rules and illegal in Islmaic law because it sells government protected goods and cause damage to nature.
\end{abstract}

Keywords: Buy and sell, Islamic law 


\section{PENDAHULUAN}

Manusia merupakan makhluk ciptaan Allah Swt. yang paling sempurna dibanding dengan makhluk lainnya. Namun selain itu, manusia juga merupakan makhluk sosial yang tidak dapat hidup sendiri utamanya dalam hal memenuhi kebutuhan hidupnya, manusia satu dengan lainnya akan saling membutuhkan. Manusia dianugerahi oleh Allah Swt. naluri yang menjadikannya gemar memperoleh manfaat dan menghindari mudharat, serta membenci lawan kedua hal itu. Tidak ada perbedaan manusia menyangkut hal ini sejak kehidupan dikenal oleh makhluk. Seimbang dengan kekurangan dan kelebihannya, demikian juga kesenangan dan kebenciannya. Untuk meraih apa yang disenanginya, atau menampik apa yang tidak disukainya, lahirlah dorongan fitrah yang mengantar kepada aneka aktifitas manusia. ${ }^{1}$

Dalam memenuhi kebutuhan manusia ada berbagai cara yang dilakukan, misalnya dengan perniagaan (jual beli), sewa menyewa, pinjam meminjam dan lain sebagainya. Hal ini pula yang dimaksud dalam ilmu ekonomi, sebagaimana pengertian ekonomi yaitu terdiri dari dua kata, oicos dan nomos, yang masing-masing artinya "rumah tangga" dan "norma-norma atau aturan". Dari dua pengertian kata tersebut maka dapat diartikan bahwa ekonomi adalah cara atau aturan-aturan dalam memenuhi kebutuhan rumah tangga manusia.

Islam sebagai Agama rahmatan lil 'alamin membuat hukum sedemikian rupa guna kemaslahatan umatnya,tidak terkecuali dunia ekonomi. Sistem Islam ini berusaha mendialektikakan nilai-nilai ekonomi dengan nilai akidah ataupun etika. Artinya, kegiatan ekonomi yang dilakukan manusia dibangun dengan dialektika nilai materialisme dan spiritualisme. Sehingga kegiatan ekonomi yang dilakukan tidak hanya berbasis materi, akan tetapi terdapat spiritual di dalamnya, sehingga kegiatan ekonomi ini bernilai ibadah.

Islam telah membuat semua peraturan dan larangan dalam jual beli untuk mendatangkan kemaslahatan dan menghindarkan dari kemudharatan, tujuannya agar terjadi transaksi yang adil dan tidak merugikan satu sama lain. Namun para pelaku pelanggaran dalam bermuamalah kini kian banyak, bahkan dianggap sebagai hal yang lumrah terjadi. Tanpa mereka sadari ada dampak yang ditimbulkan dari kegiatan yang mereka anggap biasa saja. Demikian halnya yang terjadi di lingkungan Jambu Tua kelurahan Darma kecamatan polewali kabupaten Polewali Mandar.

Lingkungan Jambu Tua merupakan satu dari beberapa desa/lingkungan yang berada dipinggiran sungai kelurahan Darma kecamatan Polewali yang masyarakatnya banyak yang berprofesi sebagai penambang batu. Penambang batu disini ialah mereka yang melakukan penambangan di sungai yang bekerja mengambil dan mengumpulkan batu di sungai yang kemudian dijual kepada pembeli. Dengan kondisi sungai yang mengandung banyak material seperti batu serta banyaknya proyek pembangunan, hal ini menjadi peluang bagi masyarakat sekitar untuk berbondong-bondong mengumpulkan semua batu-batu yang ada di sungai tersebut.

Pokok permasalahan dari kasus di atas yaitu pemanfaatan dan pengambilan kandungan sungai sebagai salah satu sumber pendapatan yang berujung pada kerusakan

\footnotetext{
${ }^{1}$ M. Quraish Shihab, Berbisnis Dengan Allah, (Tangerang : Lentera Hati , 2008), h. 1
} 
alam. Adanya aktivitas usaha jual beli batu sungai tersebut mendatangkan mudharat yang menyebabkan habisnya kandungan batu disekitaran sungai yang mengakibatkan semakin terkikisnya tanah/lahan yang ada dipinggiran sungai, rusaknya kondisi fisik sungai, serta mudahnya debit air naik saat musim hujan. Oleh karena itu, dari uraian latar belakang di atas penulis bermaksud membahas dan mengkaji lebih dalam mengenai usaha jual beli batu sungai tersebut dengan penelitian yang berjudul "Praktek Jual Beli Batu Sungai dalam Tinjauan Hukum Islam “ (Studi Kasus Di Lingkungan Jambu Tua Kelurahan Darma Kecamatan Polewali Kabupaten Polewali Mandar).

Berdasarkan uraian latar belakang masalah diatas, maka rumusan masalah yang akan dikaji dalam penelitian yaitu :

1. Bagaimana mekanisme jual beli batu sungai di lingkungan Jambu Tua kelurahan Darma kecamatan Polewali ?

2. Bagaimana tinjauan hukum Islam terhadap jual beli batu sungai di lingkungan Jambu Tua kelurahan Darma kecamatan Polewali ?

\section{KAJIAN PUSTAKA}

\section{A. Pengertian jual beli}

Jual beli atau dalam istilah fiqh disebut al bai' menurut etimologi berarti menjual atau mengganti. Menurut bahasa pengertian jual beli (al bai') adalah tukar menukar secara mutlak. Dari pengertian tersebut dapat dipahami bahwa jual beli menurut bahasa adalah tukar menukar apa saja, baik barang antara barang dengan barang, barang dengan uang, atau uang dengan uang ${ }^{2}$.

Hukum asal jual beli adalah mubah (boleh), sebagaimana dijelaskan pada kaidah fiqh bahwa hukum asal dalam semua bentuk muamalah adalah mubah (boleh) dilakukan, kecuali ada dalil yang mengharamkannya (melarangnya). Berikut adalah dalil-dalil dari ayat al-Quran, dalam Q.S. Al- Baqarah/2: 275 sebagai berikut:

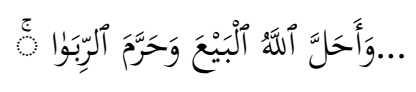

Terjemahnya:

...Padahal Allah telah menghalalkan jual beli dan mengharamkan riba.. ${ }^{3}$.

Dari kandungan ayat Allah di atas, para ulama' fiqh mengatakan bahwa hukum asal dari jual beli adalah mubah (boleh).

Rukun jual beli ada tiga sebagaimana disebutkan dalam Al-majmu' karya alNawawi, yaitu sebagai berikut:

a. Pihak yang mengadakan akad (mencakup penjual dan pembeli)

b. Shighat (ijab-qabul)

c. Barang yang menjadi objek akad (harga dan barang yang diperjualbelikan).

Beberapa prinsip yang diterapkan dalam melaksanakan jual beli antara lain, sebagai berikut ${ }^{4}$ :

\footnotetext{
${ }^{2}$ Ahmad Wardi Muslich, Fiqh Muamalat, (jakarta: Amzah , 2015), h. 174

${ }^{3}$ Departemen Agama RI, al-Qur'an dan terjemahnya, (Kudus: Menara Kudus) h. 47

${ }^{4}$ Mardani, Fiqh Ekonomi Syariah, (jakarta: kencana, 2003), h. 7-11
} 

a. Prinsip Tauhid
b. Prinsip halal
c. Prinsip maslahah
d. Prinsip Ibahah
e. Prinsip kebebasan bertransaksi

\section{B. Pengertian Hak Milik}

Hak milik merupakan hubungan antara manusia dengan harta yang ditetapkan dan diakui oleh syara'. Karena adanya hubungan tersebut, ia berhak melakukan berbagai macam tasarruf terhadap harta yang dimilikinya. Secara bahasa milik artinya menguasai sesuatu dan bebas melakukan tasarruf terhadapnya. Secara istilah hak milik adalah suatu kemampuan untuk melakukan tasarruf sejak awal kecuali karena adanya penghalang.

Sebab kepemilikian harta adalah sebab (cara) yang ditetapkan syariah bagi seorang muslim untuk memperoleh harta pertma kalinya. Sebab kepemilikan harta dalam islam, yaitu:

a. Penguasaan, ada beberapa mediasi yang digunakan manusia untuk menguasai harta orang lain tnapa melalui usaha keras atau perniagaan. Contohnya warisan dan wasiat.

b. Kepemilikan barang-barang halal, dimana seseorang memiliki sesuatu yang belum dimiliki orang lain, seperti mencari kayu bakar di hutan atau mencari ikan di laut.

c. Transaksi, diantaranya adalah transaksi barang seperti jual beli

d. Keputusan hakim terhadap perubahan status kepemilikan umum seperti tentang tanah dan perkebunan

e. Zakat, nafkah, hasil denda

f. Wakaf

\section{Hukum Islam Terhadap Perilaku Pengrusakan Alam}

Al Qur'an dan sunnah telah memperingatkan kepada manusia untuk tidak mencelakakan diri dan sekitarnya. Dalam Al Qur'an terdapat beberapa ayat yang berbicara tentang lingkungan dan larangan merusaknya. Sebagaimana dalam Q.S. Al A'raaf/7 :56, sebagai berikut:

Terjemahnya:

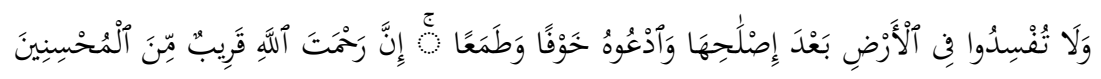

Dan janganlah kamu membuat kerusakan di muka bumi, sesudah (Allah) memperbaikinya dan berdoalah kepada-Nya dengan rasa takut (Tidak akan diterima) dan harapan (akan dikabulkan). Sesungguhnya rahmat Allah amat dekat kepada orang-orang yang berbuat baik. ${ }^{5}$

Adanya larangan pengrusakan di muka bumi dalam Al Qur'an dimaksudkan untuk memelihara lima unsur penting dalam syariat Islam yang mesti dijaga, yakni jiwa, agama, akal, keturunan, dan harta yang merupakan tujuan penetapan syariat (maqhasid asy-asyariah). Oleh karena itu seluruh tindakan yang mengarah pada tindakan yang dapat merusak lima elemen penting tersebut merupakan tindakan yang dilarang oleh agama.

\footnotetext{
${ }^{5}$ Departemen Agama RI, al-Qur'an Dan Terjemahnya, h. 157
} 
Segala aktivitas yang menimbulkan mudharat hukumnya perbuatannya adalah haram dan terlarang menurut Agama. Kerusakan yang terjadi di muka bumi tentunya akan menimbulkan berbagai bahaya (mudharat) bagi keberlangsungan makhluk hidup di dalamnya ${ }^{6}$.

Dalam hal ini pemerintah memiliki peran penting dalam melindungi dan menjaga kelestarian alam dan lingkungan hidup. Oleh karena itu kegiatan penambangan batu atau pengambilan batu-batuan yang ada di sungai diatur dalam hukum positif negara dalam undang-undang nomor 4 tahun 2009 tentang pertambangan mineral dan batu bara dikelola berasaskan manfaat, keadilan, dan keseimbangan, keberpihakan kepada kepentingan bangsa, partisipatif, transparansi, dan akuntabilitas, berkelanjutan dan berwawasan lingkungan hidup. Serta kegiatan yang dapat menimbulkan kerusakan lingkungan alam diatur dalam undang-undang nomor 23 tahun 2009 tentang perlindungan dan pengelolaan lingkungan hidup. Aturan pertambangan juga diatur dalam peraturan daerah kabupaten Polewali Mandar (perda) nomor 5 tahun 2013 tentang pengelolaan usaha pertambangan rakyat yang harus sesuai dengan aturan pemerintah setempat.

\section{METODE PENEITIAN}

Penelitian dapat didefenisikan sebagai upaya mencari jawaban yang benar atau suatu masalah berdasarkan logika dan didukung oleh fakta empirik. Dapat pula dikatakan bahwa penelitian adalah kegiatan yang dilakukan secara sistematis melalui proses pengumpulan data, pengolahan data, serta menarik kesimpulan berdasarkan data menggunakan metode dan teknik tertentu. Pengertian tersebut menyiratkan bahwa penelitian adalah langkah sistematis dalam upaya pemecahan masalah. ${ }^{7}$ Jenis dari penelitian ini adalah penelitian deskriptif (description research). Tujuan penelitian deskriptif adalah untuk menggambarkan/memecahkan masalah secara sistematis, faktual, dan akurat mengenai fakta-fakta dan sifat-sifat populasi atau daerah tertentu. ${ }^{8}$ Penelitian deskriptif merupakan penelitian paling sederhana, dibandingkan dengan penelitianpenelitian yang lain karena dalam penelitian ini peneliti tidak melakukan apa-apa terhadap objek atau wilayah yang diteliti. Ini artinya bahwa dalam penelitian, peneliti tidak mengubah, menambah, atau mengadakan manipulasi terhadap objek atau wilayah penelitian. ${ }^{9}$

Adapun yang akan menjadi lokasi penelitian yaitu sungai yang berada di lingkungan Jambu Tua kelurahan Darma kecamatan Polewali kabupaten Polewali Mandar. Pendekatan penelitian dapat dilakukan dengan dua pendekatan, yaitu pendekatan kuantitatif dan kualitatif, adapun yang digunakan dalam skripsi ini merupakan pendekatan kualitatif. Penelitian kualitatif adalah penelitian yang bermaksud untuk memahami fenomena tentang apa yang dialami oleh subjek penelitian misalnya perilaku, persepsi, motivasi, tindakan, dan lain-lain secara holistic dan dengan cara deskripsi dalam bentuk

\footnotetext{
${ }^{6}$ Reflita, Eksploitasi Alam Dan Perusakan Lingkungan (Istinbath Hukum Atas Ayat-ayat Lingkungan), h. 155-156

${ }^{7}$ Puspowarsito, Metode penelitian Organisasi, (Bandung, Humaniora, 2008), h. 78

${ }^{8}$ Usman Rianse dan Abdi, Metodologi Penelitian Sosial dan Ekonomi Teori dan Aplikasi, (Bandung: Alfabeta, 2012), h. 30

${ }^{9}$ Puspowarsito, Metode penelitian Organisasi, h. 71
} 
kata-kata dan bahasa, pada suatu konteks khusus yang alamiah dan dengan memanfaatkan berbagai metode alamiah. ${ }^{10}$

Pada penelitian kualitatif data dikumpulkan umumnya berbentuk kata-kata, gambar-gambar, dan kebanyakan bukan angka-angka, kalaupun ada angka-angka sifatnya hanya sebagai penunjang, data yang dimaksud meliputi transkip wawancara, catatan data lapangan , foto-foto, dokumen dan catatan lainnya. ${ }^{11}$

Dalam penelitian sangat membutuhkan data. Data-data yang dijadikan acuan dalam penelitian ini di ambil dari berbagai sumber, diantaranya :

1. Data Primer, contoh data primer adalah data yang diperoleh dari responden melalui wawancara. Hasil dari data primer ini digunakan untuk menjawab pertanyaan pada rumusan masalah pertama.

2. Data Sekunder, diperoleh melalui buku-buku, brosur, artikel, yang didapat dari website yang berkaitan dengan penelitian ini. Untuk memperoleh data ini peneliti mengambil sejumlah buku-buku, brosur, website, dan contoh penelitian sebelumnya yang berkaitan dengan penelitian ini ${ }^{12}$. Adapun hasil dari pengolahan data sekunder ini digunakan untuk menemukan jawaban dari rumusan masalah kedua dari penelitian ini.

Metode pengumpulan data adalah bagian instrument pengumpulan data yang menentukan berhasil atau tidaknya suatu penelitian ${ }^{13}$. Berikut adalah metode pengumpulan data yang digunakan dalam penelitian ini yaitu:

1. Metode Wawancara

2. Observasi

3. Dokumentasi

Pada prinsipnya meneliti adalah melalukan pengukuran, maka tentu terdapat alat ukur yang baik. Alat ukur dalam penelitian biasanya dinamakan instrument penelitian. Adapun instrumen penelitian merupakan suatu alat yang digunakan mengukur fenomena alam maupun sosial yang diamati, secara spesifik semua fenomena ini disebut variabel penelitian. ${ }^{14}$ Instrumen kunci dalam penelitian ini adalah peneliti sendiri. Adapun instrumen lain yang digunakan oleh peneliti yaitu alat tulis dan handphone untuk dokumentasi serta membantu kelancaran proses penelitian.

Analisis data hasil penelitian akan dilakukan dengan beberapa cara untuk memperoleh hasil yang diinginkan dan sesuai dengan keadaaan yang sebenarnya yaitu :

1. Melakukan peringkasan data, yang mana dari data mentah hasil pengumpulan data, data diseleksi kemudian disederhanakan dan di ambil intinya.

2. Data disajikan secara tertulis berdasarkan kasus-kasus faktual yang saling berkaitan. Tampilan data digunakan sebagai alat untuk memahami apa yang sebenarnya.

3. Menarik kesimpulan tertentu dari hasil pemahaman dan pengertian peneliti.

${ }^{10}$ Lexy J. Moleong,Metode Penelitian Kualitatif, (PT Remaja Rosakarya Bandung, 2004, Cet.20),h. 6 .

${ }^{11}$ Sudarwan danim, Menjadi peneliti Kualitatif, ( Pustaka setia,2002), h. 61

${ }^{12}$ Sutrisno Hadi, Metodologi Research, Jilid I, (Yogyakarta; Andi Offset, 1997), h. 47

${ }^{13}$ Ahmad Tanzeh, Pengantar Metodologi Penelitian,(Yogyakarta:Teras), h. 123

${ }^{14}$ Sugiyono, Metode Penelitian Kuantitatif Kualitatif dan R\&D , h. 102 
Ketiga komponen analisis di atas dilakukan secara interaktif yaitu saling berhubungan selama dan sesudah pengumpulan data. Proses analisis data mengalir sehingga tidak menjadi kacau dari tahap awal sampai akhir.

\section{HASIL PENELITIAN}

\section{Mekanisme Jual Beli Batu Sungai Di Lingkungan Jambu Tua Kelurahan} Darma Kecamatan Polewali

Berdasarkan observasi yang dilakukan oleh peneliti bahwa awal mula adanya kegiatan jual beli batu sungai di Lingkungan Jambu Tua yaitu pada tahun 1994 yang masih berlanjut hingga sekarang. Batu yang banyak diambil dari sungai ada 2 (dua) jenis yaitu batu kecil atau biasa disebut kerikil dan batu besar biasa disebut dengan batu pondasi. Narasumber pertama yang peneliti temui untuk melakukan wawancara adalah ibu Hana, salah satu pemungut sekaligus penjual batu (dikenal dengan istilah pakkarikiil). Kepada narasumber peneliti menanyakan tentang berapa harga batu sungai persatuan dan bagaimana cara penentuan harga batu sungai tersebut.

"penentuan harga batu sungai telah ditentukan bersama oleh para pedagang dan pembeli batu. Sudah ada harga yang menjadi patokan bagi para pembeli untuk membeli batu. Satuan harga batu yang digunakan yakni gerobak. Harga batu pergerobak sebesar Rp. 4.000 (empat ribu rupiah) untuk batu kecil (kerikil) dan untuk batu besar (batu pondasi) sebesar Rp. 5.000 (lima ribu rupiah) pergerobak. Harga tersebut tidak berubah sejak kurang lebih 5 tahun lalu. Banyak sedikitnya permintaan batu sungai harganya tetap sama". ${ }^{15}$

Selanjutnya peneliti melakukan wawancara dengan narasumber yang lain, yaitu bapak jamaluddin selaku pembeli batu. Peneliti menayakan tentang alasan bapak Jamaluddin membeli batu sungai.

"dengan adanya masyarakat yang mengumpulkan batu sungai sehingga para pembeli batu membawa beberapa mobil truk ke dalam kawasana sungai untuk mengangkut batu yang telah dikumpulkan, tanpa harus menunggu dan mengumpulkan sendiri batu yang ingin dibawanya. Biasanya dalam perhari ada kurang lebih 5 sampai 10 mobil truk datang mengangkut batu sungai dengan alasan pembelian batu untuk keperluan proyek pembangunan jalan dan jembatan , terkadang juga untuk pembangunan rumah atau gedung. ${ }^{16}$

Berdasarkan pengamatan peneliti dan keterangan yang didapatkan dari narasumber, maka dapat diketahui bahwa alasan utama masyarakat memungut dan menjual batu sungai ialah karena tuntutan faktor ekonomi. Dalam kondisi masyarakat yang kebutuhannya semakin meningkat setiap hari dan tidak mencukupinya lapangan pekerjaan di daerah tersebut membuat masyarakat memilih jalan menjual batu sungai untuk mendapatkan penghasilan dengan harga yang sudah ditentukan yakni sebesar Rp. 4.000 (empat ribu rupiah) per gerobak. Jika menjual batu sungai dijadikan pekerjaan utama, maka setiap harinya batu yang ada di sungai diambil dan dikumpulkan lalu

\footnotetext{
${ }^{15}$ Hana (42 tahun), selaku penjual batu, masyarakat Lingkungan Jambu Tua Kelurahan Darma, Wawancara, Jambu Tua, 14 September 2019

16 Jamaluddin (39 tahun), selaku pembeli batu, masyarakat Lingkungan Jambu Tua Kelurahan Darma, wawancara, Jambu Tua, 20 September 2019
} 
kemudian dijual oleh masyarakat. Hal ini menandakan bahwa setiap hari juga batu-batu yang ada di sungai tersebut berkurangJika sudah tidak ada batu yang bisa diambil dipermukaan sungai maka pemungut batu ini menggali sungai tersebut sampai ia mendapatkan batu di dalamnya. Hal ini yang menyebabkan sungai semakin dalam dan luas karena batu-batu yang menjadi penahan tanah di pinggir sungai sudah tidak ada.

Peneliti kemudian melakukan wawancara dengan bapak Uki selaku orang yang mengatur keluar masuknya mobil truk pengangkut batu ke dalam sungai dan yang mengetahui serta mencatat batu siapa saja yang telah diangkut mobil truk tetapi pembayarannya belum dilunasi. Kepada bapak Uki peneliti menanyakan tentang berapa banyak batu yang mampu dihasilkan setiap orang dalam sehari dan berapa banyak batu yang terkumpul dalam sebulan.

"biasanya dalam sehari setiap orang mampu mengumpulkan batu 10 sampai 15 gerobak perhari. Jadi dalam sebulan rata-rata batu yang diangkut sebanyak 190 - 220 mobil dengan jumlah penjual batu (pemungut batu) yang tidak menentu kadang banyak kadang juga sedikit. Akan tetapi setap harinya pasti ada yang datang mengumpulkan batu.",17

Dari keterangan bapak Uki maka diketahui bahwa jumlah batu yang berkurang dalam setiap bulan kurang lebih 200 truk. Menurut peneliti jumlah tersebut cukup banyak, mengingat batu yang ada sungai tidak dengan mudah timbul menggantikan batubatu yang telah diambil.

Kemudian peneliti menanyakan hal kepada bapak Baharuddin selaku masyarakat Jmbu Tua yang juga merupakan pemilik lahan (kebun) yang ada dekat pinggir sungai.

"dampak yang ditimbulkan dari kegiatan tersebut membuat tanah di pinggir sungai longsor sampai-sampai lahan (kebun) yang awalnya sedikit jauh dari sungai kini sudah mulai ikut terkikis terbawa arus jika kadar air sungai naik. Hal ini karena masayarakat yang memungut batu di sungai menggali sampai ke pinggiran sungai untuk mengambil batunya sehingga tidak ada penahan tanah jika arus air deras. Mudahnya air sumur mengering juga merupakan salah satu dampak yang saat ini sangat dirasakan masyarakat lingkungan Jambu tua. Hal ini karena sungai yang semakin digali dalam membuat dasar air juga semakin dalam. Sehingga masyarakat yang memiliki sumur diatas dari dasar sungai akan mudah mengering atau airnya habis. Dan memang dampak fisik sungai yang sekarang terlihat semakin rusak."

Dari keterangan narasumber, diketahui bahwa ada beberapa dampak yang ditimbulkan dari kegiatan jual beli ini yaitu keadaan fisik sungai yang jelas berubah (rusak) karena kurangnya batu-batu yang ada, semakin luas atau melebarnya permukaan sungai karena longsor dipinggir sungai yang diakibatkan tidak adanya batu sebagai penahan arus air, semakin dalamnya dasar sungai karena digali untuk mendapatkan batunya, mudahnya sumur masyarakat mengering karena dasar air semakin dalam sungai dan merusak lahan masyarakat yang ada dekat sungai.

17 Uki (36 Tahun), selaku pengelola penjualan batu, masyarakat Dusun basseang, wawancara, Jambu Tua 28 september 2019

${ }^{18}$ Baharuddin (48 Tahun) selaku pemilik lahan (kebun), masyarakat Lingkungan Jambu Tua Kelurahan Darma, wawancara, Jambu Tua 1 oktober 2019 
Lebih lanjut, peneliti menanyakan tentang kepedulian masyarakat dan kesadaran masyarakat mengenai dampak tersebut terhadap lingkungan.

"jelas terlihat bahwa kurangnya kepedulian masyarakat terhadap lingkungan dengan terus mengumpulkan dan menjual batu-batu yang ada di sungai. Masyarakat yang menjual batu tersebut tidak sadar telah melakukan tindakan yang merusak lingkungan yang nantinya akan perimbas pada pemukiman warga sekitar."

Menjadikan kebutuhan sebagai alasan masyarakat menjual batu sungai memang hal yang lumrah dikalangan masyakarat menengah kebawa. Tetapi hal tersebut bukan menjadi alasan untuk melakukan hal yang dapat menimbulkan mudharat bagi masyarakat yang lain. Lalu bagaimana kondisi tingkat kerusakan yang saat ini dirasakan masyarakat.

Selanjutnya peneliti melakukan wawancara dengan aparat Desa atau Lingkungan dalam hal ini bapak Muhammad Syahrir selaku kepala Lingkungan Jambu tua, tentang aturan pemerintah setempat mengenai pengelolaan sumber daya alam.

"sebenarnya tambang yang dilakukan oleh masyarakat disini tidak resmi (illegal) karena jika merujuk pada aturan yang ada bahwa sepanjang 1,5 kilometer dari bendungan tidak boleh ada penambangan atau pengambilan material sungai, sedangkan lokasi masyarakat mengambil batu disini kurang dari 1 kilometer. Selaku aparat pemerintah, kami sudah beberapa kali melakukan peneguran dan peringatan kepada masyarakat yang mengambil material sungai (batu sungai), akan tetapi tidak pernah diindahkan dengan alasan kebutuhan proyek pembangunan dan tidak adanya pekerjaan lain yang bisa dilakukan selain mengambil batu-batu sungai dan menjualnya untuk memperoleh penghasilan. Karena alasan itulah penambangan itu masih berlangsung sampai sekarang sejak kurang lebih 10 tahun yang lalu. Sehingga kami selaku kepala lingkungan berharap adanya tindak tegas dan solusi dari pihak pemerintah atas demi kelestarian sungai dimasa yang akan datang. "19

Dari hasil wawancara dengan kepala Lingkungan Jambu Tua selaku aparat pemerintah di daerah tersebut. Maka dapat dianalisa bahwa dalam praktek jual beli batu sungai yang dilakukan oleh masyarakat Lingkungan Jambu Tua tidak mendapat izin resmi dari pemerintah karena adanya larangan dari pemerintah setempat untuk tidak mengambil material batu yang ada di sungai tersebut. Sehingga praktek jual beli batu sungai yang dilakukan oleh masyarakat Lingkungan Jambu Tua tidak sah atau tidka boleh dilakukan karena barang yang dijual tersebut dapat mengakibatkan kerusakan alam serta barang yang menjadi objek jual beli tersebut merupakan barang yang dilindungi oleh pemerintah dan berdasarkan aturan perda kabupaten polewali mandar nomor 5 tahun 2013 tentang pengelolaan usaha pertambangan rakyat dan undang-undang nomor 4 tahun 2009 tentang pertambngan mineral dan batu bara yang tidak sesuai dengan praktek yang dilakukan oleh masyarakat Lingkungan Jambu Tua.

\section{Tinjauan Hukum Islam Terhadap Jual Beli Batu Sungai Di Lingkungan Jambu Tua Kelurahan Darma Kecamatan Polewali}

${ }^{19}$ Muh. Syahrir (47 tahun), Selaku kepala lingkungan Jambu Tua Kelurahan darma, wawancara, jambu tua 20 Desember 2019 
Jual beli merupakan aktivitas tukar menukar barang apa saja antara penjual dan pembeli yang berakibat pada berubahnya hak milik dan kepemilikan. Sebagaimana dasar hukum muamalah adalah mubah (boleh) selama tidak ada dalil yang melarangnya, maka begitupun dengan jual beli yang merupakan salah satu bentuk Muamalah dasar hukum pelaksanaannya juga boleh. Kecuali yang secara tegas diharamkan seperti mengakibatkan kemudharatan, tipuan, judi, dan riba ${ }^{20}$. Sebagaimana firman Allah tentang jual beli dalam Q.S. Al- Baqarah/2: 275 sebagai berikut:

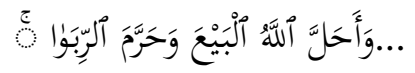

Terjemahnya:

...Padahal Allah telah menghalalkan jual beli dan mengharamkan riba.. ${ }^{21}$.

Dalam menjalani kehidupannya, manusia dituntut untuk selalu berusaha memenuhi segala kebutuhan hidupnya demi keberlangsungan hidup yang baik. Jual beli merupakan salah satu aktivitas yang paling banyak dilakukan manusia untuk memperoleh penghasilan demi memenuhi kebutuhan hidupnya setiap hari, mengingat Rasulullah Saw. Juga adalah seorang pedagang yang menjual barang dagangannya kepada orang lain (pembeli). Namun dalam segala aktivitas apapun, ada beberapa hal yang harus diperhatikan agar tidak menyimpang dari syariat. Begitupun dengan transaksi jual beli harus diperhatikan mulai dari segala rukun dan syarat jual beli hingga manfaat dan mudharat yang ditimbulkan dari aktivitas tersebut.

Menurut peneliti transaksi jual beli batu sungai yang dilakukan oleh masyarakat Lingkungan Jambu Tua tidak memenuhi salah satu rukun dan syarat jual beli. Adapun rukun dan syarat jual beli dalam syariat Islam, yaitu :

a. Adanya kedua belah pihak yang melakukan akad (penjual dan pembeli),

syaratnya telah dewasa, baligh dan berakal serta tidak ada unsur paksaan dari kedua belah pihak. Rukun ini sesuai dengan transaksi jual beli yang dilakukan oleh masyarakat Lingkungan Jambu Tua yakni adanya masyarakat sebagai penjual batu/pakkarikil dan masyarakat luar yang datang sebagai pembeli batu.

\section{b. Sighat (ijab qabul)}

Transaksi jual beli diharuskan adanya ijab qabul, adanya pernyataan yang menggambarkan terjadinya transaksi jual beli, baik secara lisan maupun tertulis. Bentuk sighat yang dilakukan masyarakat Lingkungan Jambu Tua dalam praktek jual beli batu sungai yaitu dengan akad secara lisan yang sudah menjadi kebiasaan dan ketentuan yang berlaku di masyarakat.

c. Barang yang menjadi objek jual beli, yaitu barang harus suci, barang berguna menurut syariat islam, barang dapat diserahkan, barang diketahui kedua belah pihak, dan barang hak milik penjual. Dalam hal ini objek/barang yang masyarakat Lingkungan Jambu Tua perjualbelikan adalah batu sungai yang merupakan barang suci karena tidak termasuk dalam kategori barang-barang yang dihukumi najis, dari sisi kegunaannya batu merupakan barang yang sangat berguna dalam bidang pembangunan, batu yang

\footnotetext{
${ }^{20}$ Djazuli, Kaidah-kaidah fikih (Kaidah-kaidah Hukum Islam dalam menyelesaikan Masalah-masalah yang Praktis), (jakarta: Kencana, 2014), h. 130

${ }^{21}$ Departemen Agama RI, al-Qur'an dan terjemahnya, (Kudus: Menara Kudus) h. 47
} 
dikumpulkan oleh masyarakat/penjual di sungai merupakan barang yang dapat diserahkan kepada pembeli, batu sungai yang menjadi objek jual beli tidak jelas hak kepemilikannya atau dengan kata lain barang yang dijual bukanlah hak milik penjual sepenuhnya karena adanya larangan dari pemerintah setempat untuk tidak mengambil batu sekitar sungai tersebut dengan kata lain barang yang diperjualbelikan merupakan barang yang dilindungi oleh pemerintah, dan batu itu diketahui oleh kedua belah pihak yang bertransaksi karena telah sama-sama mengetahui spesefikasi dari objek barang yang diperjualbelikan.

Secara teori, transaksi jual beli yang dilakukan oleh masyarakat Lingkungan Jambu Tua terkait jual beli batu sungai hukumnya tidak sah, karena rukun dan syarat sah jual beli yang meliputi penjual dan pembeli (Aqidain), Sighat, dan Ma'qud alaih tidak terpenuhi. Dalam hal ini terdapat kecacatan dalam objek jual beli (ma'qud 'alaih) yakni penjual telah menjual barang yang dilindungi oleh pemerintah tanpa izin dari pemerintah setempat.

Praktek jual beli yang dilakukan oleh masyarakat Lingkungan Jambu Tua yakni berupa penjual atas sumber daya alam berupa batu yang terkandung di dalam sungai Lingkungan Jambu Tua yang merupakan wilayah yang dilindungi oleh pemerintah setempat. Efek buruk dari kegiatan ini adalah kerusakan atas struktur sungai yang berdampak pula pada kerusakan lingkungan yang sangat parah.

Hal ini bertentangan dengan Firman Allah Swt. Dalam Q.S al-Qashash/28 : 77 yang berbunyi :

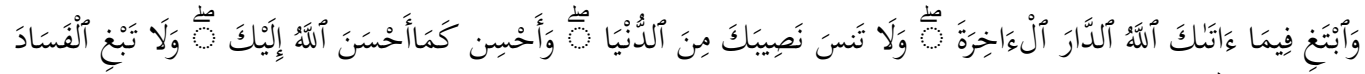

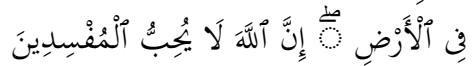

Terjemahnya:

Dan carilah pada apa yang telah dianugerahkan Allah kepadamu (kebahagiaan)negeri akhirat, dan janganlah kamu melupakan bahagianmu dari (kenikmatan) duniawi, dan berbuat baiklah (kepada orang lain), sebagimana Allah telah berbuat baik kepadamu, dan janganlah kamu berbuat kerusakan di (muka) bumi. Sesungguhnya Allah tidak menyukai orang-orang yang berbuat kerusakan. $^{22}$

Dari keterangan ayat diatas dapat dipahami bahwa, Allah memberikan hambanya kebebasan dalam mencari anugerah Allah di muka bumi, tetapi Allah juga memberi peringatan agar dalam mengelola karunia Allah dapat dilakukan dengan bijak, dan dalam usaha mengelola karunia Allah agar tidak berbuat kerusakan di muka bumi, karena Allah tidak menyukai orang-orang yang berbuat kerusakan.

\footnotetext{
${ }^{22}$ Departemen Agama RI, al-Qur'an Dan Terjemahnya, h. 394
} 
Dilihat dari sudut pandang hukum mu'amalah, menurut pangamatan peneliti jual beli yang dilakukan tersebut tidak sesuai dengan salah satu prinsip jual beli. Beberapa prinsip yang diterapkan dalam melaksanakan jual beli antara lain, sebagai berikut ${ }^{23}$ :

a. Prinsip Tauhid

Prinsip tauhid adalah dasar utama dari setiap bentuk bangunan yang ada dalam syariat islam. Hal tersebut berarti bahwa setiap gerak langkah serta bangunan hukum harus mencerminkan nilai-nilai ketuhanan. Sehingga dalam jual beli harus memperhatikan nilai-nilai ketuhanan. Setidaknya dalam setiap jual beli ada keyakinan dalam hati bahwa Allah selalu mengawasi seluruh gerak langkah kita dan selalu berada bersama kita.

b. Prinsip halal

Umat islam diharapkan dalam mencari rezeki menjauhkan diri dari hal-hal yang haram. Melaksanakan hal-hal yang halal, baik dalam cara memperoleh, mengonsumsi, dan memanfaatkannya. Selain caranya harus halal, barang yang diperjualbelikan juga harus halal.

c. Prinsip maslahah

Maslahah adalah sesuatu yang ditunjukkan oleh dalil hukum tertentu yang membenarkan atau membatalkannya atas segala tindakan manusia dalam rangka mencapai tujuan syara', yaitu memelihara agama, jiwa, akal, harta benda, dan keturunan. Oleh karena itu, praktik jual beli yang tidak mendatangkan maslahah kepada masyarakat harus ditinggalkan karena tidak sesuai dengan syariat Islam.

d. Prinsip Ibahah

Yaitu pada dasarnya segala sesuatu itu boleh dilakukan selama belum ada dalil yang melarangnya. Ini maksudnya bahwa kemubahan untuk melakukan akad terhadap objek apa saja selama sesuai dengan hukum yang ada.

e. Prinsip kebebasan bertransaksi

Prinsip kebebasan bertransaksi harus tetap didasari dengan prinsip suka sama suka dan tidak ada pihak yang didzalimi dengan didasari oleh akad yang sah. Disamping itu, transaksi tidak boleh dilakukan pada barang-barang haram

Prinsip yang tidak sesuai dengan praktek jual beli yang dilakukan oleh masyarakat Lingkungan Jambu Tua yakni prinsip maslahah, karena dalam praktek ini banyak menimbulkan kemudharatan bagi masyarakat Lingkungan Jambu Tua itu sendiri. Hal ini berdasarkan pengamatan dan keterangan dari beberapa narasumber, salah satunya bapak baharuddin ketika ditanya mengenai dampak yang dirasakan dengan adanya kegiatan transaksi jual beli tersebut.

"dampak yang ditimbulkan dari kegiatan tersebut membuat tanah di pinggir sungai longsor sampai-sampai lahan (kebun) yang awalnya sedikit jauh dari sungai kini sudah mulai ikut terkikis terbawa arus jika kadar air sungai naik. Hal ini karena masayarakat yang memungut batu di sungai menggali sampai ke pinggiran sungai untuk mengambil batunya sehingga tidak ada penahan tanah jika arus air deras. Mudahnya air sumur mengering juga merupakan salah satu dampak yang saat ini sangat dirasakan masyarakat lingkungan Jambu tua. Hal

\footnotetext{
${ }^{23}$ Mardani, Fiqh Ekonomi Syariah, (jakarta: kencana, 2003), h. 7-11
} 
ini karena sungai yang semakin digali dalam membuat dasar air juga semakin dalam. Sehingga masyarakat yang memiliki sumur diatas dari dasar sungai akan mudah mengering atau airnya habis. Dan memang dampak fisik sungai yang sekarang terlihat semakin rusak. "24

Berdasarkan keterangan dari narasumber, maka diketahui bahwa kegiatan ini telah menimbulkan dampak kerusakan pada alam (sungai) yang tidak dibenarkan dalam Islam. Sebagaimana Firman Allah Swt. dalam Q.S. Ar-Rum/30:41 sebagai berikut:

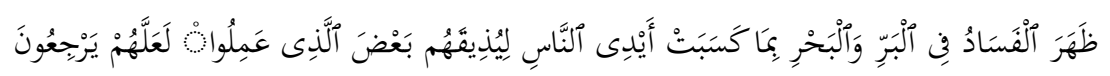

Terjemahnya:

Telah nampak kerusakan di darat dan di laut disebabkan Karena perbuatan tangan manusia, supaya Allah merasakan kepada mereka sebahagian dari (akibat) perbuatan mereka, agar mereka kembali (ke jalan yang benar). ${ }^{25}$

Ayat di atas menjelaskan bahwa rusaknya alam atau terjadinya sebuah bencana alam terdapat hubungannya dengan apa yang dilakukan oleh manusia. Abul "Aliyah mengatakan bahwa barang siapa yang berlaku maksiat kepada Allah Swt. di muka bumi, maka berarti dia telah berbuat kerusakan di dalamnya. Karena kebaikan bumi dan langit adalah sebab ketaatan ${ }^{26}$.

Hukum dan aturan jual beli dalam Islam menjadi hal yang sangat diprioritaskan. Hal tersebut dikarenakan jika akad jual belinya tidak sesuai dengan tata aturan yang ditetapkan oleh syariat, maka dapat dipastikan akad jual belinya dianggap tidak sah. Jika demikian keadaannya, maka akan terjadi kezdaliman terhadap pihak lain yang saling melakukan transaksi, padahal Islam senantiasa mengatur umatnya agar hidup berdampingan dan tidak saling merugikan.

Selain itu kegiatan ini juga tidak mendapat izin resmi dari pemerintah setempat dalam artian kegiatan jual beli batu sungai ini merupakan tambang ilegal. Karena tidak sesuai dengan aturan pemerintah dalam Perda kabupaten Polewali Mandar nomor 5 tahun 2013 tentang pengelolaan pertambngan rakyat dan Undang-undang nomor 4 tahun 2009 tentang pertambangan seperti yang telah dijelaskan pada bab sebelumnya. Sebagaimana yang dikemukakan oleh kepala Lingkungan Jambu Tua bapak Muh. Syahrir.

"sebenarnya tambang yang dilakukan oleh masyarakat disini tidak resmi (illegal) karena jika merujuk pada aturan yang ada bahwa sepanjang 1,5 kilometer dari bendungan tidak boleh ada penambangan atau pengambilan material sungai, sedangkan lokasi masyarakat mengambil batu disini kurang dari 1 kilometer. Selaku aparat pemerintah, kami sudah beberapa kali melakukan peneguran dan peringatan kepada masyarakat yang mengambil material sungai (batu sungai), akan tetapi tidak pernah diindahkan dengan alasan kebutuhan

${ }^{24}$ Baharuddin (48 Tahun) selaku pemilik lahan (kebun), masyarakat Lingkungan Jambu Tua Kelurahan Darma, wawancara, Jambu Tua 1 oktober 2019

${ }^{25}$ Departemen Agama RI, al-Qur'an Dan Terjemahnya, h. 408

${ }^{26}$ M. Abdul Ghoffar E.M, Tafsir Ibnu Katsir, Jilid 6, (Bogor: Pustaka Imam Syafi'i, 2014) h. 380 
proyek pembangunan dan tidak adanya pekerjaan lain yang bisa dilakukan selain mengambil batu-batu sungai dan menjualnya untuk memperoleh penghasilan. "27

Berdasarkan penjelasan diatas dapat dianalisa bahwa praktek jual beli batu sungai yang dilakukan oleh masyarakat Lingkungan Jambu Tua Kelurahan Darma Kecamatan Polewali hukumnya tidak sah dilakukan karena batu yang menjadi objek jual beli tersebut merupakan barang yang dilindungi pemerintah karena adanya larangan dari pemerintah setempat untuk tidak mengambil batu di sekitar sungai tersebut berdasarkan undangundang dan perda yang berlaku. Praktek jual beli ini juga tidak sesuai dengan prinsip maslahah yang harusnya diterapkan dalam transaksi jual beli. Praktek jual beli batu sungai tersebut menimbulkan dampak kerusakan pada lingkungan dan sungai tersebut, sehingga menimbulkan kemudharatan bagi masyarakat lain di Lingkungan Jambu Tua.

\section{KESIMPULAN}

1. Mekanisme jual beli batu sungai yang dilakukan oleh masyarakat Lingkungan Jambu Tua yakni masyarakat mengumpulkan batu-batuan yang ada di permukaan sungai sampai beberapa meter ke pinggiran sungai dengan cara menggali untuk mendapatkan batunya. Setelah itu batu yang telah dikumpulkan dijual kepada pembeli dengan harga yang telah ditentukan. Pada dasarnya jual beli ini boleh saja dilakukan akan tetapi semakin lama kegiatan ini sudah menyimpang dari aturan pemerintah yang berlaku sebagaimana diatur dalam Undang-undang Nomor 4 Tahun 2009 tentang pertambangan dan Perda Nomor 5 Tahun 2013 tentang pengelolaan pertambangan rakyat Karena dari kegiatan tersebut timbul berbagai macam dampak buruk, dantaranya; merusak struktur sungai, membuat dasar air sungai semakin dalam, dan dampak buruk kerusakan lingkungan yang bersifat materi, yang semua itu akan dirasakan oleh masyarakat Lingkungan Jambu Tua pada umumnya.

2. Tinjauan hukum Islam terhadap praktek jual beli batu sungai yang terjadi di Lingkungan Jambu Tua Kelurahan Darma Kecamatan Polewali, hukumnya tidak sah dan tidak boleh dilakukan karena baarang yang diperjualbelikan merupakan barang yang dilindungi oleh pemerintah karena tidak sesuai dengan aturan yang berlaku. Dan praktek jual beli batu sungai yang dilakukan menimbulkan kerusakan struktur sungai dan alam sekitar serta menimbulkan kemudharatan bagi masyarakat lain. Hal ini tidak sesuai dengan prinsip maslahah yang harus diterapkan dalam transaksi jual beli.

27 Muh. Syahrir (47 tahun), Selaku kepala lingkungan Jambu Tua Kelurahan darma, wawancara, jambu tua 20 Desember 2019 


\section{DAFTAR PUSTAKA}

Al Qur'an dan Terjemahnya.

Abdulloh. Tinjauan Hukum Islam Terhadap Praktik Jual Beli Pasir Sungai Pabelan Di Dusun Blangkunan Pabelan Mungkid Magelang, Skripsi, Yogyakarta: Uin Sunan Kalijaga, 2003.

Arikunto, Suharsimi. Manajemen Penelitian. Jakarta: Rineka Cipta, 2010.

Azzam, Abdul Aziz Muhammad. Fiqh Muamalat. Jakarta: Amzah, 2010.

Bungin, Burhan. Metode Penelitian Kuantitatif Komunikasi Ekonomi Dan Kebijakan Publik Serta Ilmu-Ilmu Sosial Lainnya. Jakarta: Kencana, 2005.

Damin, Sudarwam. Menjadi Peneliti Kualitatif. Jakarta: Pustaka Setia, 2002.

Djazuli. Kaidah-Kaidah Fikih (Kaidah-Kaidah Hukum Islam Dalam Menyelasaikan Masalah-Masalah Yang Praktis). Jakarta: Kencana, 2014.

Ghaffar, M. Abdul e.M. Tafsir Ibnu Katsir. Jilid 6. Bogor: Pustaka Imam Syafi'i. 2014.

Ghazali, Abdul Rahman. Fiqh Muamalat. Jakarta: Kencana, 2010.

Hadi, Sutrisno. Metode Research. Jilid I. Yogyakarta: Andi Offset, 1997.

Haroen, Nasrun. Fiqh Muamalah. Jakarta: Gaya Media Pratama, 2007.

Hasan, M. Ali. Berbagai Macam Transaksi Dalam Islam (Fiqh Muamalat). Jakarta: Raja Grafindo Persada, 2003.

Mahmud. Metode Penelitian Pendidikan. Cet. I. Bandung: Cv. Pustaka Setia, 2011.

Mardani. Fiqh Ekonomi Syariah. Jakarta: Kencana, 2003.

Moleong, Lexy J. Metode Penelitian Kualitatif. Cet. 20. Bandung: PT. Remaja Rosakarya, 2004.

Mughniyah, Muhammad Jawad. Fiqh Imam Ja'Far Sadiq. Jilid 2. Jakarta: Penerbit Lentera, 2009.

Al Mushlih, Abdullah Dan Ash Shawi. Fikih Ekonomi Islam. Jakarta: Darul Haq, 2015.

Muslich, Ahmad Wardi. Fiqh Muamalat. Jakarat: Amzah, 2015.

Negara, Departemen Pendidikan RI. Kamus Besar Bahasa Indonesia. Cet. I. Jakarta: Balai Pustaka, 1995.

Pasha, Mustafa Kamal. Fiikih Islam. Yogyakarta: Citra Karsa Mandiri, 2009.

Prasetyo, Bambang. Metode Penelitian Kuantitatif Teori Dan Aplikasi. Jakarta: Grafindo, 2005.

Prasetyo, Eko. Kajian Al Qur'an Dan Sains Tentang Kerusakan Lingkungan. Jurnal Ilmu al Qur'an Dan Hadits. Volume 12 Nomor 1. 2018.

Puspowarsito. Metode Penelitian Organisasi. Bandung: Humaniora, 2008.

Rasjid, Sulaiman. Fiqh Islami. Bandung: Sinar Baru Algesindo, 2010.

Reflita. Eksploitasi Alam Dan Pengrusakan Lingkungan (Istinbath Hukum Atas AyatAyat Lingkungan). Jurnal Subtantia. Volume 17 Nomor 2. 2015.

Rianse ,Usman Dan Abdi. Metodologi Penelitian Sosial Dan Ekonomi Teori Dan Aplikasi. Bandung: Alfabeta, 2012.

Sahrani, Sohari Ru'fah Abdullah, Fikih Muamalah. Bogor: Ghalia Indonesia, 2011. 
Shihab, M. Quraish. Berbisnis Dengan Allah. Tangerang: Lentera Hati, 2008.

Siti Maemanah. "Tinjauan Hukum Islam Terhadap Praktik Jual Beli Pasir Kali Serayu Dengan Sistem Rit Di Desa Cindage Kecamatan Kebasen Kabupaten Banyumas", Skripsi. Purwokerto: Fak. Syari'ah, 2018.

Sugiyono. Metode Penelitian Kuantitatif Kualitatif Dan R \& D. Bandung: Alfabeta, 2014.

Suhendi, Hendi. Fiqh Muamalah. Jakarta: Raja Grafindo Persada, 2005.

Syarifuddin, Amir. Garis-Garis Besar Fiqh. Jakarta: Kencana, 2010.

Al Zuhaili, Wahbah. Fiqh Imam Syafi'i. Terjemahan Muhammad Afifi, Abdul Hafidz. Jilid I. Jakarta: Almahira, 2012. 